\title{
Existence of Melaka Malay (Fort) City Based on First Painting of A'Famosa by The Portuguese
}

\author{
KamarulAfiziKosman, Noor AisyahMokhtar
}

\begin{abstract}
The Melaka Malay City during Malay Sultanate era often mentioned in historical writing of Malay world as one of the great, majestic and powerful Malay cities. The city's context of this paper defined as the administrative area of the Melaka Malay government before the Portuguese colonization in 1511. Its existence is still doubtful since there is no clear physical evidence as basis support to its existence. Thus, this study aims to identify historical evidence that mentioned its existence which based on the first painting of A'Famosa (Melaka Fort City during Portuguese era). The scope focuses only on the physical building (which is believed to be historical evidence) of the city at the Melaka River's estuary. The method focused on this paper is through historical sources, scientific writing, previous studies globally as well as relevant scientific records. This research trying to prove that the city indeed exists in historical writing and the city was a square-shaped which fit in the philosophy and Malay's way of life. The implication of this study can be a catalyst for continuous and deeper research on the original site of the Melaka Malay City as to prove the validity of its existences. This paper expected to serve as a basis for further research using satellite mapping technologies to know and understand the existence, position and layout of the city. In conclusion, first painting of A'Famosa shows the design was in square or rectangular shape as it was built on the site of the Great Mosque of Melaka. The rectangular fort design was synonym with the design of other Malay forts or cities as rectangular design was a fundamental design tradition in the Malay world. Hence, the city existence should be examined to rebuild the knowledge of Melaka and Malay civilization.
\end{abstract}

\section{Keywords: Existence, Malay City, Melaka, square design.}

\section{INTRODUCTION}

Recognized by UNESCO as a world heritage city, Melaka is not known as a symbol of the origin of Malaya or Malaysia, but the recognition refers to the old buildings of colonial and immigrants from outside Malaya since the reign of Melaka Malay Sultanate until the colonial period. Hence, the nature and character of Malaya and the Malays which are the foundation of the Melaka empire's origins, were historically absent or was not recognized by the world. In fact, such recognition seems to convey that the outrage of outsiders is more meaningful than the destroyed empire. The attitude of accepting by the present generation in Malaysia or the world over recognition seems to deny the existence and ability of the ruling during Melaka Malay Sultanate that had great history of the past. This also weakening the desire to dismantle and seek evidence of the great kingdom.

\footnotetext{
Revised Manuscript Received on September 14, 2019.

Noor Aisyah Mokhtar, Institute of Malay World and Civilization, Universiti Kebangsaan Malaysia, Selangor, Malaysia. aisyah.mokhtar@gmail.com

Kamarul Afizi Kosman, Pusat Kajian Seni Bina dan Alam Bina Inovatif (SErAMBI), Fakulti Kejuruteraan dan Alam Bina, Universiti
} Kebangsaan Malaysia, Selangor, Malaysia. kamarulafizi@gmail.com
Denying the existence of the Melaka Malay City also means denying the existence of Melaka Malay empire, which was widely stated in the Nusantara's historical record and also conquerors' records from the West as a great empire hence its heritage. Heritage refers to cultural significance, knowledge and expertise through the way of life, cultural entities, and lifestyle. It symbolizes the civilization of community in a place. Preservation of the heritage assets is beneficial to future generations and local community in terms of social, economics and politics [1].

However, to prove that the city was existed, various physical and scientific evidence are required to prove its existence. Without physical evidence such as the original site and the building materials, this will continue to be a constant debate in the historical world since Melaka Malay Empire had went through urbanization process. Urbanization Process Urbanization often said to be one of the changes that will trigger the development and progress of a society [2], which defined the great kingdom of Melaka. This paper attempts to uncover and reveal the historical evidence of Melaka Malay (Fort) City before the city was destroyed and rebuilt according to colonial terms. This paper was created to identify the differences between designs and layout plans of the Melaka Malay (Fort) City and the worldrenowned Fort A'Famosa, thus comparing the hypothesis arguments about the existence of Melaka City. Indeed, there is a clear distinction between the design, layout, character and philosophy of the Malay and Portuguese cities anthropometrically and ergonomically of Asian or Melaka people that defined their culture and architecture.Anthropometry and ergonomic are among of the design fundamental knowledge which the establishment of the human anthropometric data is a crucial process for the product and spatial design development, whereas, ergonomic refers to the study on how the product can be designed comfortably, safely, and effectively [3] as traditional Malay architecture or houses once known for its technological achievement in the past of wood-built structures, mortises and many climate-based solutions. As this knowledge now facing extinction as a result of the ignorance of the modern Malay community of its existence, this research is important not only because it is able to unearth hidden aspects relating to the Malay's design, planning and construction but also because it will help to cultivate pride and self-esteem among the Malays through the knowledge of their technological heritage [4]. 

PORTUGUESE

\section{LITERATURE REVIEW}

\section{A. Similar Research on Proving the Existence of 'Vanished' City}

There are many proving studies of 'vanished' cities around the world. However, this paper set some standards about 'vanished' city proof studies as the main reference. This standard refers to the historical background of the city, the similarity of socio-cultural and economic background, the process of urban design development, colonization or conquest of the city, renovation of the city after the conquer, colonization and modification factors, city destruction, analysis and research findings about the city, and further studies that will be undertaken on the city.

Those are the priorities because the Melaka Malay city is a unique city with architecture that goes through all the above processes. Historical background of Melaka's emperor also brings the historical value, culture and expertise of its people. This in turn, forms a diverse socio-cultural and economic background when setting up a new government elsewhere. As a 'young' government, the design and development of the city through a thorough, long process and in line with the prosperity of the Melaka government through time. This process that takes hundreds of years is a symbolic and strength of the physical character of the Melaka Malay Empire. It is because during the reign of the government to be built up to that current strength and richness, there must have been diplomatic ties that were also promoting the trade and exchange of knowledge and expertise gained from trading or visiting countries. This affects the emulation of new ideas to the physical character of Melaka according to the style and pattern of that current government administration.

Furthermore, the colonization and conquest aspects of the city are an essential characteristic that needs consideration because it is the biggest turning point to the physical landscape of the Melaka Malay City that transforms part or the entire Melaka Malay city. Destruction and renovation done for the obvious reasons of damaging or destroying the original design of the Malacca Malay City made the city only exist in historical records and vanish from the land. These factors make Melaka Malay City a complex and difficult subject to study. Therefore, the analysis of the findings of other cities that have the same factors as Melaka Malay history have become the main importance of this study.

In order to adopt another city-proof study similar to Melaka Malay study, it is difficult to achieve as many city proof studies are not as complex as the Melaka Malay City. There was a study about a city that still have physical structures with little damage or renovation and there is also study on a completely destroyed city. However, in order to find a similar study that went through the same process of establishment and development, thus possessing wealth such as the Melaka Malay Empire, and subsequently through the city's physical occupation and colonial process, then building a new city on the original building and ruins of the old city, later colonized by other nations and went through renovations, which finally destroyed by other invaders - are too complicated and difficult to exactly look for similar studies.
Consequently, after searching and studying literature on the study of other cities around the world as far as this paper is written, there is no exact any basic study similar to the Melaka Malay Fortification Study nor Melaka Malay City. However, albeit the results of studies and research on cityproving studies around the world (although there is no similar case with the Melaka Malay City), there are still various combinations of study methods, interpretation methods of evidence obtained, logical submissions on the remains of the city records and historical evidence, which later with the growing technologies of satellite and computer software can be used for further studies of this paper. Hence, there is a great probability of continuing this study into the use of satellite technology in determining and identifying the Melaka Malay City with more precise and accurate details. Conducting a digital reconstruction, which would digitally preserve valuable field data that could otherwise be compromised. Moreover, digital models provide opportunities for hypothetical anastylosis to be thoroughly analyzed before physical reconstruction is carried out, ensuring that the structure is accurately represented [5].

\section{B. Malay City and Fort}

The meaning of 'Kota' (city) and 'Kubu' (fort) in the context of Malay township and architecture depends on the meaning, sentence and method of use of the word [6]. City can mean a town, place with main business or a whole settlement with lots population. The city is also associated with community logistics, where people living in cities are often referred to as urban societies. While communities living in villages called rural or rural communities. The word 'city' also means 'fortress' or fortress with administrative center of the Malay rulers during the reign of the former Malay government, in this context - Melaka Malay Empire

According to [6], cities and fortresses have different roles. In all ancient Malay texts, the word city is often associated with the palace of the Malay rulers. It is because when a Malay king established a new state, the king would direct his people to build a royal palace - a complex of royal palaces completes with the BalaiPenghadapan, BalaiBesar, Balairung and other buildings belonging to the king that must be located within a fenced area. This fence can be constructed of any material, whether wood, bamboo, ground brick, stone wall and so on. The enclosed palace complex area around it is called 'Istana Berkota' or Fortess Palace. The central government also serves as a center of defense that also houses the ruling kings' residence, complete with various facilities and other important buildings such as gathering hall, facing hall, trial center, religious building, food warehouse, treasury warehouse, carpark and much more. The city must also be paraded around the city of mined land and put water into it as a barrier of enemy attacks. This fortress palace means strong city fortress complete with armed guard. 
While, fortress might have the same design and construction material as the kota (city), but the function of fort is only as a defense center [6]. Therefore, the fort is usually complete with a defensive fort made of dumped soil or a wooden spin that arranged horizontally known as a 'fence bridge'. The fort also has armed guards guarding the fort. Nevertheless, in the fortress there is no house or king's palaces with all its conveniences like a city. Fortress works solely as a defense fort but it is the important infrastructure that protects the city of a kingdom.

There are dozens of cities and fortresses found in Malaya during the reign of the Malay empire. The study conducted by [6] and the national museum for twelve years found 87 sites of Malay cities with 44 sites still have the effects of the city either fortress and wall fortress made of stone slabs or stone. Most of the sites were found in the state of Kedah and Perlis with 28 urban sites found where 20 sites still have the effects of cities and fortifications that can be studied because they are constructed of clear soil and bricks. A study in Perak found 22 sites in the Malay Archipelago with 11 sites still being studied. In Johor, there are 12 city sites, mostly located along the Johor River with 6 of them still being studied. The towns in Johor began to build after Sultan Mahmud Syah fled Malacca after the Portuguese captured Malacca in 1511.

In the history of Kelantan, there are many city names called Kota SerendahSekebunBunga, Mahligai City, Jelasin City, Bukit Marak City, City of Madiun, City of Semesta, Kota Bharu, Sabar Island City, KubangLabu City and several other names. But there are only a few cities that can still be studied, among them KubangLabu City while others only exist in historical records. Terengganu also has several city names in historical records such as the City of Bukit Puteri, Pelimbang City, Kemahang City, Kota Lama and several other cities but the city has disappeared altogether. Pahang is almost completely non-existent, but Pahang's history refers to an old town located in Pekan, the town of Biram, which is now the founding site of the Sultan Abu Bakar Museum.

In Melaka there is a Malay town on the banks of Sungai Linggi and Sungai Rembau, Kota Simpang. In Malay History and many Portuguese records mention the existence of the Melaka Malay City that was established since the time of Parameswara, but physical evidence about it has not been confirmed since it is likely that the city was destroyed or underneath the construction of the colonial era of Portuguese and Dutch. Negeri Sembilan has only a Malay town of Lukut City in Port Dickson built by Raja Jumaat to safeguard the interests of the company.

In [7] said that the design and construction of the Malay cities undergoes changes in terms of construction materials in the colonial era. Cities in the Old Malay kingdoms like in Kedah and Perak, the form of more fortified cities formed by high land boundaries, the Malay cities in the 15th century were constructed using neatly arranged solid rocks and the height of city construction is the construction of a city wall composed of red brick bonds and walls plastered with glue as cement. The architecture of the Malay town is very simple, rectangular and surrounded by trenches. The location and position of the Malay towns is located in the area near the river and some are located in the highlands.
Cities built close to the river (kuala), usually because the river is a trade route and trade gateway. The cities located on a hill like Kota Lukut allow the guards and rulers to see the vivid views of the nearby marine naval traffic in addition to ensuring city safety. It is arguable that the Malay towns and fortresses built throughout the 15 th century until the late 17 th century have defensive features because at that time, the Malay government often received threats from the enemy especially from Siam and the Portuguese as the city wall was also built two layers of wall with cannons.

\section{METHODOLOGY}

In an effort to discuss the existence of this Melaka Malay City, various aspects and methods were conducted to find the most suitable matches and comparisons that almost accurately describe their design then prove its existence. The remains and plans of Melaka City today since the British era will be the basis of its existence. Hence, the study of historical records and sketches of the Melaka City from the Dutch government and subsequently the Portuguese will be made to seek physical evidence of the earliest design of Melaka City. Later, the historical records of the city from Malay Archipelago, Chinese, Portuguese and Dutch sources will be depicted in city design. As reinforcement, the philosophy of urban design in the Malay World is highlighted as well as presenting the comparison between the other Malay Kingdoms and the Melaka Malay City.

\section{MELAKA MALAY (FORT) CITY EXISTED AND WAS SQUARE-SHAPED DESIGN}

\section{A. Existence of Melaka Malay (fort) City}

Tom Pires states in the Suma Oriental a comparison between Melaka and Venice during $15^{\text {th }}$ century - "... people cannot interpret the value of Melaka for its greatness and profit. There you can get everything you want and sometimes more than you are looking for. Anyone who is a master in Melaka, like controlling Venice in Europe." [8]. 


\section{EXISTENCE OF MELAKA MALAY (FORT) CITY BASED ON FIRST PAINTING OF A'FAMOSA BY THE PORTUGUESE}

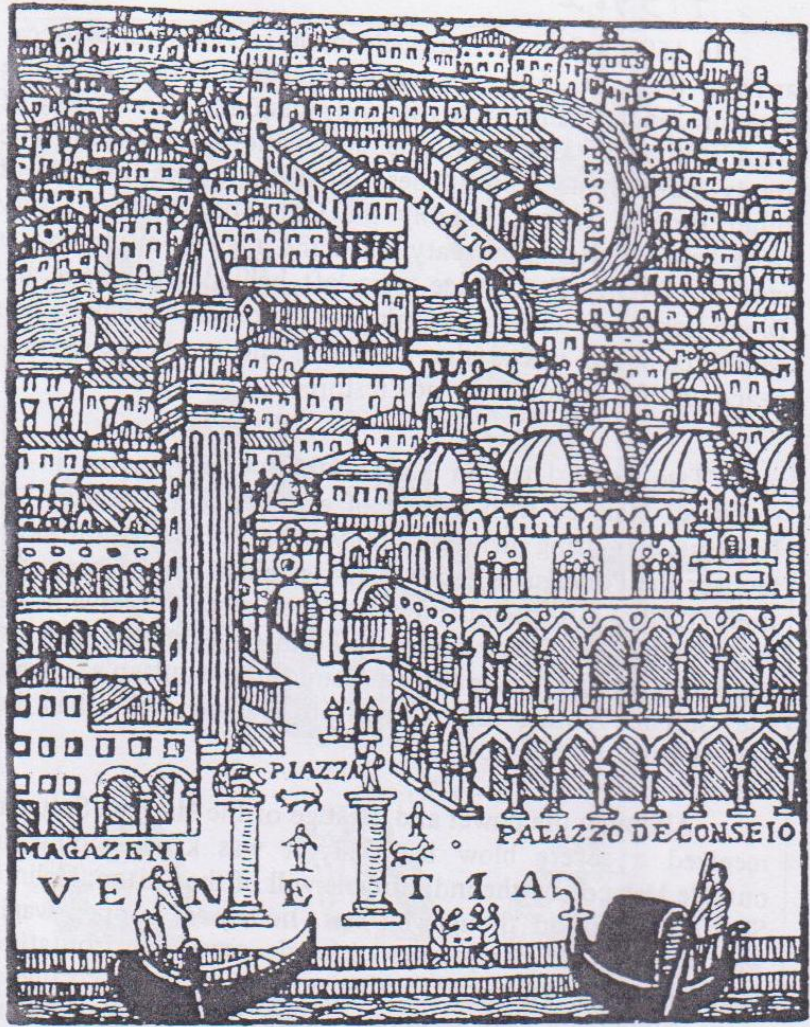

Fig. 1. Venice during 15th century that renowned as the major European trade focal city for Eastern European countries [9]. through several physical aspects - traders and buyers, the stable and prominent government also the building in the commercial city itself. Those prosperity and stability enable a port, town or physical development area and others around. Fig. 1 is a sketch of Venice as a European trading city in the 15th century. Comparison between Venice and Melaka that Tom Pires wrote provide some realistic picture of that current moment which states, first, trading activity in Melaka is equal to or more advanced than Venice. Secondly, trading activities in Melaka that connects between the West and the East could threaten the European trading activity which is centered around Venice. Thirdly, with the portrayal of the Venice City paintings, it shows that the City of Melaka also has the prosperity of commercial and physical development of the city with the same municipality or more like Venice. It is therefore possibly to acknowledge that the Malacca Malay City itself is indeed a solid brick city like Venice.

The navigational activities carried out by many of the later European countries of the Arab and Chinese explorers have established record and documentary activities of every description, geographic, physical, socio-cultural and economic picture of all the places and countries visited. The sea route explorations make painting more focused on coastal landlines and detailing drawings or sketches to everything viewed objectively, and there is likely to be no narrative or hyperbole element to all these records.

Venice in Italy in the 15 th century symbolizes the prosperity of trade in Europe. This prosperity is manifested
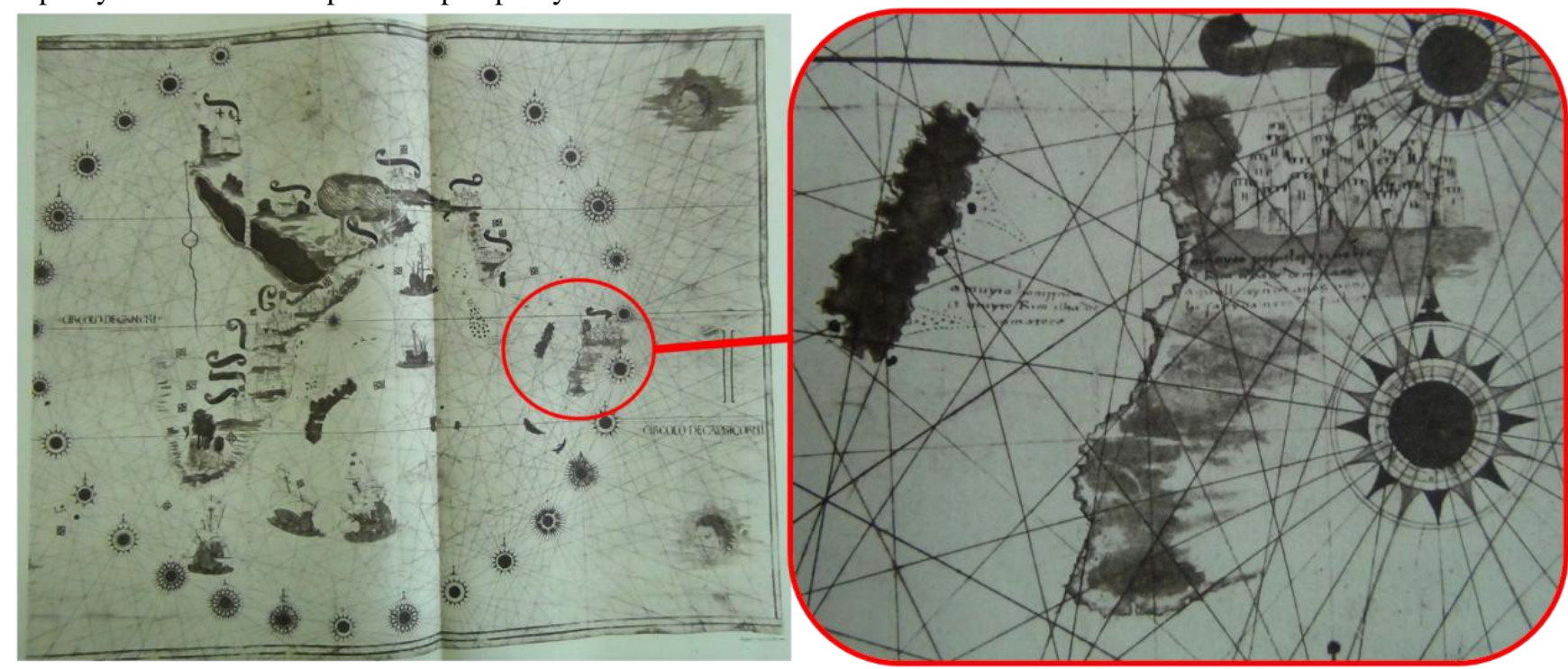

Fig. 2. The city of Melaka drawn on the map of the Western adventure sea route in 1510 clearly shows that there was a stone or brick city on the geographical position of Melaka a year before the Portuguese invaded and colonized Malacca [10].

Thus, the voyage joined by an artist or documenter Jorge Reinel in Fig. 2 is indeed something that is amazing and hardly to doubt. He describes a large, European-style rock city contrary to the small island of Sumatra (which is obviously not visited, just acknowledged and seeing the land of Sumatra Island). This European style is prevalent because of the paintings of the world map; the city on the map is painted or sketched much the same as the European-style city. A brick city with a few letters above the city's hard-to- read paintings but note that there are six or seven letters on it by ending the letter 'A' (see Fig. 2). These pictures and references seem to tell about the existence of a Malay City of Melaka, because first, this painting was made in 1510 which is a year before the Portuguese conquered Melaka.
Blue Eyes Intelligence Engineering \& Sciences Publication

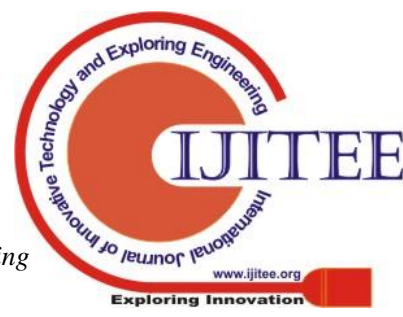


Secondly, Melaka had reached the peak of all physical development and was stable in terms of trading activity despite the weakening of the administration. Third, the only city developed and recognized throughout the world during the year in the Malay Peninsula was the Melaka City. Thus, the Reinel painting help proving that Melaka Malay City existed and its city was made of bricks. There are also a number of Portuguese records that tell about Melaka Malay City as a busy and crowded city, and are a city inhabited by wealthy merchants. These prosperity and wealth are the basis of the development of the physical civilization of the Malay Sultanate of Melaka.

While the Europeans are rapidly exploring and expanding colonies or trade routes, artists such painters and writers join in a series of explorations as the main person to record of a place or event. They can also be a spy or information provider to the military fleet as the expansionary activities of the empire expanded by European countries. The drawing series is a record or proof that is easily disputed in the arena of evidence of historical facts. This is obviously because the paintings, sketches or drawings can be objective, subjective or possess an excessive artistic and narrative element. However, a painting of a picture or a city painted at that time can be demonstrated through some x-ray methods, with contemporary watermarks, as well as the consistency of painting style and the same painting style.
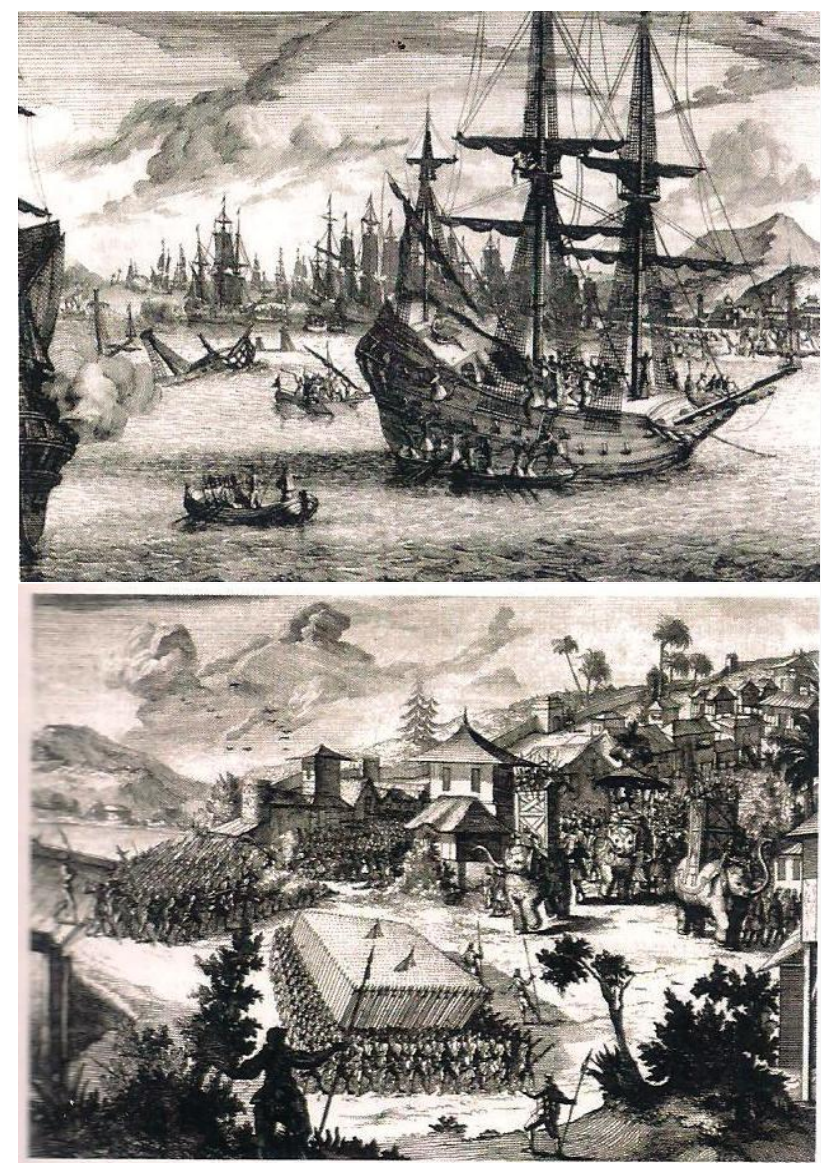

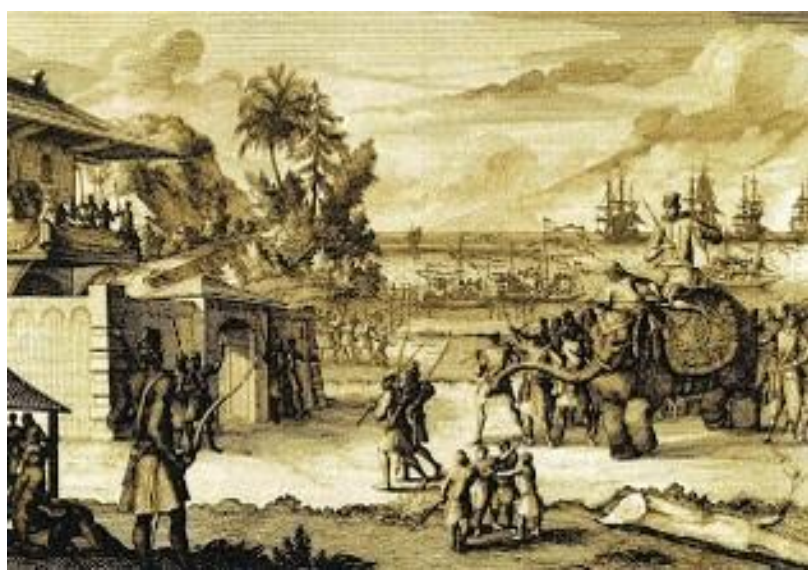

Fig. 3.Portuguese paintings about Melaka before the 1511 invasion [11].

The paintings in Fig. 3 which are the arrival and war of European governments are believed to have been painted by Dutch and Portuguese spies before they expand the colonies empire to the Asian region. It is reasonable that these drawings are intended to show the current situation of Melaka Malay City and then been analyzed before undertaking any action of power or trade expansion. They want to expand their power as their beliefs on 'Gold', 'Gospel' (religion) and 'Glory' (absorption) absorbed since the failure of the Crusades in Europe. Then, paintings need to be accurate and correct in designing the conquest strategy. In addition, the style and the way the paintings show the similarity of character during the European era at that time reinforces the trustworthy of the paintings. Unique strokes, cloud-style styles, buildings, people and paintings that are not necessarily the exact scale are the characteristics and characters corresponding to the paintings. This suggests that the paintings are more emphasizing the character of a place and city character than the artistic value of a painting.

In the paintings, there are prominent features that illustrate the empire and the Melaka City. The number of ships that came to harbor fulfilled the picture of many historical records. Melaka City included Melaka Palace, Melaka Grand Mosque, magnificent houses and administrative buildings is highlighted as brickworks with single or double storey buildings, with a majority of stone material and there are also wooden structures. This corresponds to Eredia's [15] note, Alfonso d'Albuquerque and his son who mentioned that the Portuguese era of Melaka was built on the ruins of the previous Melaka City. All three paintings show the same character so it is difficult to detect any discrepancy which in turn denies the existence of the advanced Melaka City, built with stone as a city of government and administration.

\section{B. Comparison of Portuguese and Malay Cities}

There are two similarities between the Portuguese cities and ancient Malay cities during the $15^{\text {th }}$ century when the sea route was explored around the world. First, technological advancements in each region have enabled these cities to be constructed of stronger and durable brick 


\section{EXISTENCE OF MELAKA MALAY (FORT) CITY BASED ON FIRST PAINTING OF A'FAMOSA BY THE PORTUGUESE}

building materials besides the use of wood and others. This is relevant with the city's function as a government administrative area as well as the main defense fortress of any threat. Secondly, these cities were built on high or on

flat areas along the seashore, significant with their function as a defense town where they can monitor trade activity, routes and so on from both directions of land and sea.
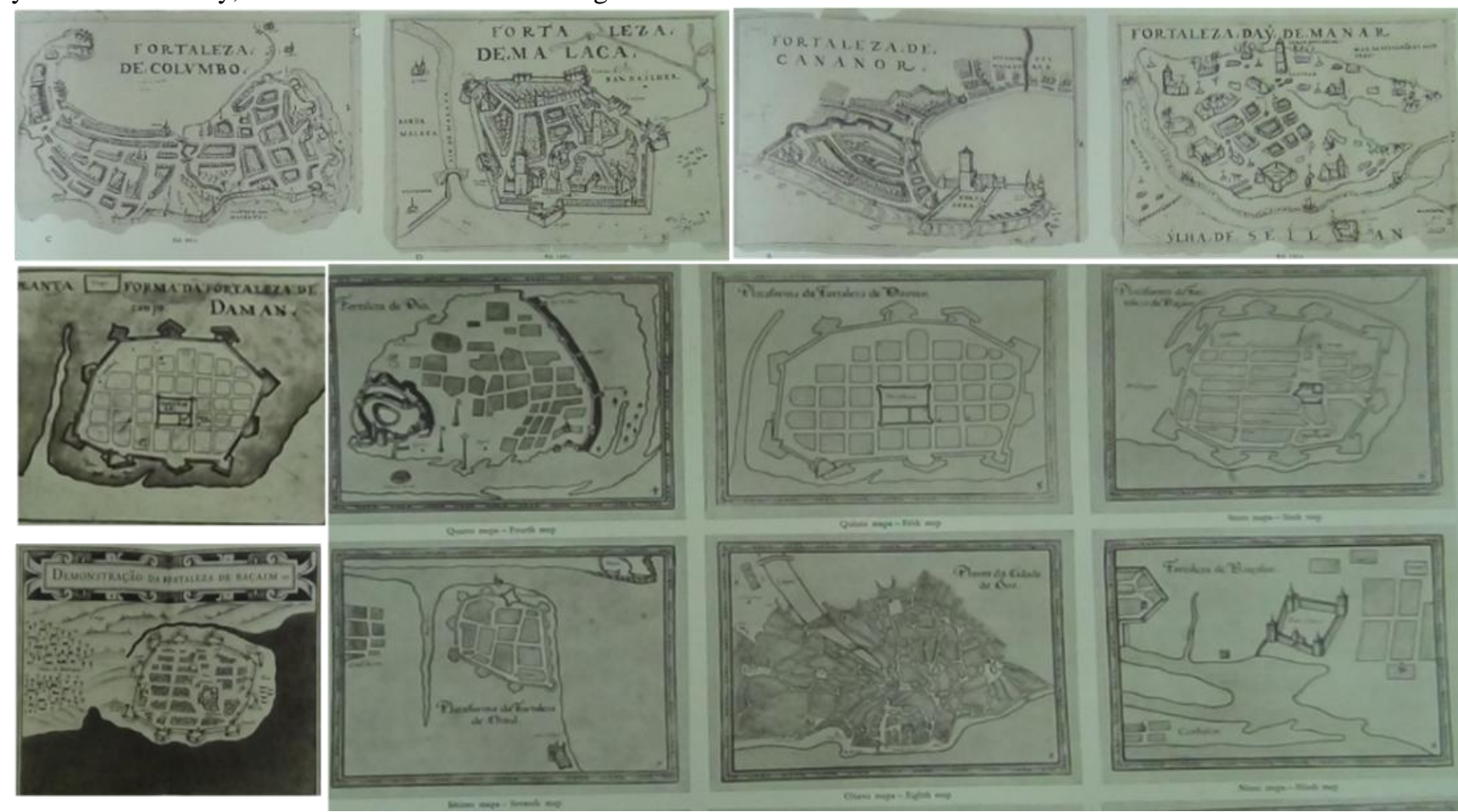

Fig. 4.Portuguese cities drawn by painters who follow Portuguese expeditions around the world [12].

But there is a significant difference detailing that the characteristic and architecture of the Portuguese's forts or city are very different from the Malay fort city. The site of the Portuguese cities was built according to the area. Established by the beaches, these cities will be built on the flat surface of the beach. If the beach is long and wide, the city built also extends and covers almost all areas. The city built in the bay was also built-in wall covering almost all the land of the existing bay area. Cities in the peninsula have walls that extend along the promontory. This can be seen on the towns plan in Fig. 1. In the Portuguese era of Melaka, the Melaka fort has been renovated to the hexagonal city fortress in accordance with the broad form of the land between the Melaka River and the Leleh River which is slightly curved to the sea, thus providing a hexagonal shape to the site of the original Melaka Fort City of rectangular origin.

Those characters were contrast to the Malay cities in the archipelago that extend beyond the Himalayan mountains to the entire Indonesian archipelago. The foundations of the Malay cities basically were designed in square or rectangular shape, no matter how far the city was set up - in the middle of the jungle, the open space, the shores, the hilly terrain and the swirling river estuary. This is in line with the philosophy in the Malay world that associated with a simple yet sufficient form of compassion that covers the various aspects of the Malay community's facilities and their living that are synonymous with modular systems. This square shape is also easily monitored, maintained and cornered to every corner of the world. In fact, the administrative center or main building of a city can be built amid the square plan and is still monitoring all other corners of the area and is in a safe distance from the city's defense fortress as well as creating majestic feel as the main building within the city area. Various philosophies also made other Malay rulers chose square design as their city plan all over Nusantara. The four elements of nature - land, water, fire and wind - are the basic philosophies that make up the square-shaped.

In the Malay Peninsula itself, most of the ancient Malay cities were built from rocks on flatland seaside or river estuary and square-shaped. The study and archaeology of the Bujang Valley as one of the earliest settlements around the fourth century in Malaya found that almost the whole complex built with a basic square plan. Despite the changing times, the square-shaped city plan remains the choice of government the splendor era of Melaka Malay Sultanate to the Portuguese, Dutch and British governments that witnessed various urban formats developed in square-shaped as Kuala Kedah City, Malawati City, Simpang City (18th century) and Lukut City (19th century).

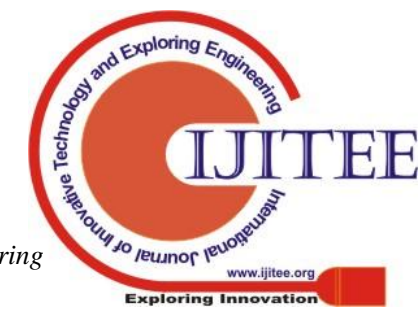




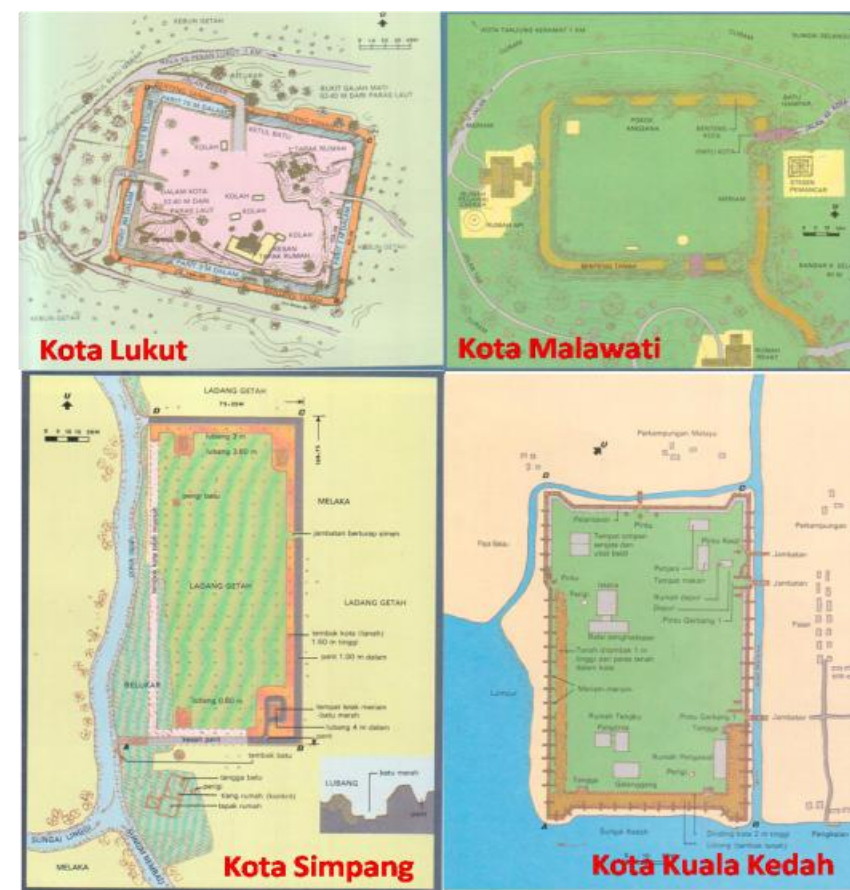

Fig. 5.The design of Malay Fort Cities from forth to nineteenth century [13].

When in exile in Bintan, Sultan Mahmud and his followers had built a defense called the Kara City. Kara City is believed to be a temporary defender built in war. It is constructed of hardwood or compressed soil and rock [6]. The Portuguese fleet led by admiral Mascarenhas with 20 ships carrying 550 Portuguese and 600 Malays have succeeded in conquering the Kara City defended by the Sultan of Mahmud under Sang Setia and Admiral Hang Nadim on October 23, 1526. After that only the city was able to conquer.

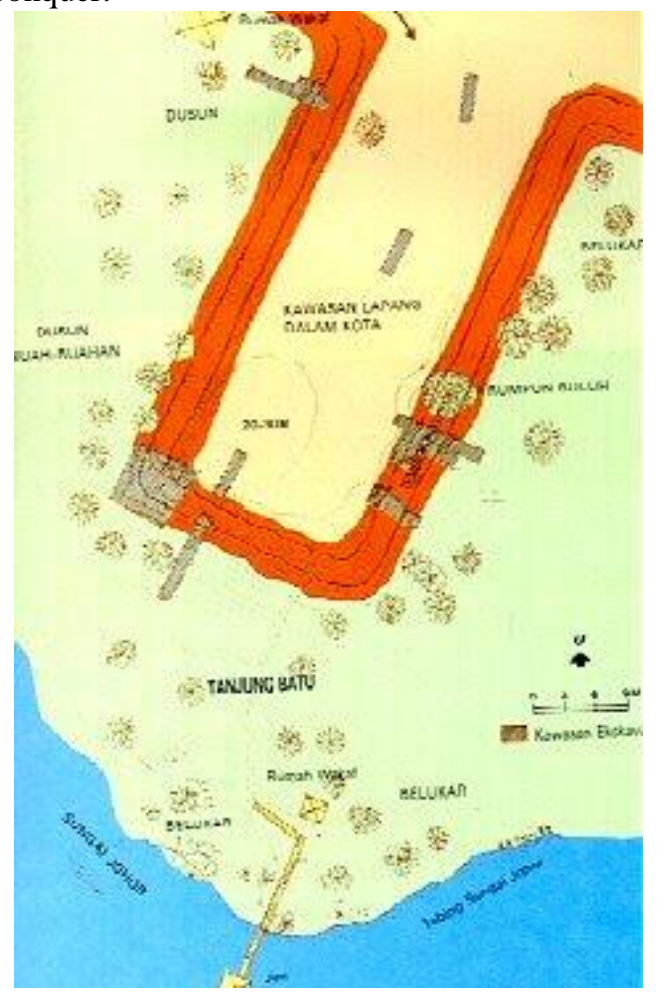

Fig. 6.The design of Kota Kara, Johor that were built after Sultan Mahmud fled from Melaka [14].
During the reign of Johor, the Old City of Johor became the administrative city of the Sultanate of Melaka Sultanate. The fort of the city which is located on TanjungBatu was using solid stone lumps and its top is covered with soil which makes the stone invisible. The city walls are covered with three-meter-wide rocks and paved cement about six centimeters which became the base and strength of the city. The wall is also equipped with hundreds of cannons to defend the city from the threat of Portuguese and other enemies.

The technology used allows the city to survive from enemy cannons. The Portuguese tried to conquer the city for over 50 years and only succeeded in 1587 and found 800 cannons inside the city. This reinforces the logic that Melaka Malays who retreated from Melaka have had high knowledge, skills and technology in the construction of the city. Of course, all that was main technology in the Old City of Johor which has been used in the construction of previous cities. In this case it is a tradition of construction and expertise inherited from the era of Melaka Malay Sultanate in Melaka.

According to a note made by [15], during the arrival of the Portuguese in Melaka, the amount of artillery owned by the kingdom was very much. 3,000 large cannons have been found in the city of Melaka while 5,000 others have been taken away by the Melaka army when the city collapsed. Albuquerque states that there are 2,000 small cannons (guns) made of copper and others made of iron. To put so many of these cannons, it certainly requires a building with solid foundation and walls like stone.

Statements and examples of design plans regarding the Portuguese and Malay cities proved that the significant difference made the architecture and design of the Malay Cities was characterized locally with a variety of other architectural influences that still retained the characteristics of a distinctive Malay architecture. This comparison explains and reinforces the previous argument that the Melaka Malay Fort City depicted in the drawings and entries from China and Europe is rational and has the real truth in terms of city overview and building materials. Therefore, it is desirable to say that the Melaka Malay Fort City was existed and follows local molds and designs with its high philosophical reasons behind the design.

\section{The First Painting of Fort A'Famosa, Melaka}

There are a number of Portuguese records stating that FortA'Famosa was built in a short period of time. This is also stated by [16] through his study published in his book, 'The Old Johore' published in the Journal of the Historical Society, 1962/3 - "Work of the fortress was begun in September 1511 and completed in the following January. According to the statement, the Portuguese developed Melaka Fort (City) which took about four months from September 1511 and is ready around January 1512. To rebuild the administration city in the ruined land and city is quite impossible or outrageous even with a large source of labor force without the raw material source for the city 


\section{EXISTENCE OF MELAKA MALAY (FORT) CITY BASED ON FIRST PAINTING OF A'FAMOSA BY THE PORTUGUESE}

itself, not to mention the surrounding residences [17].

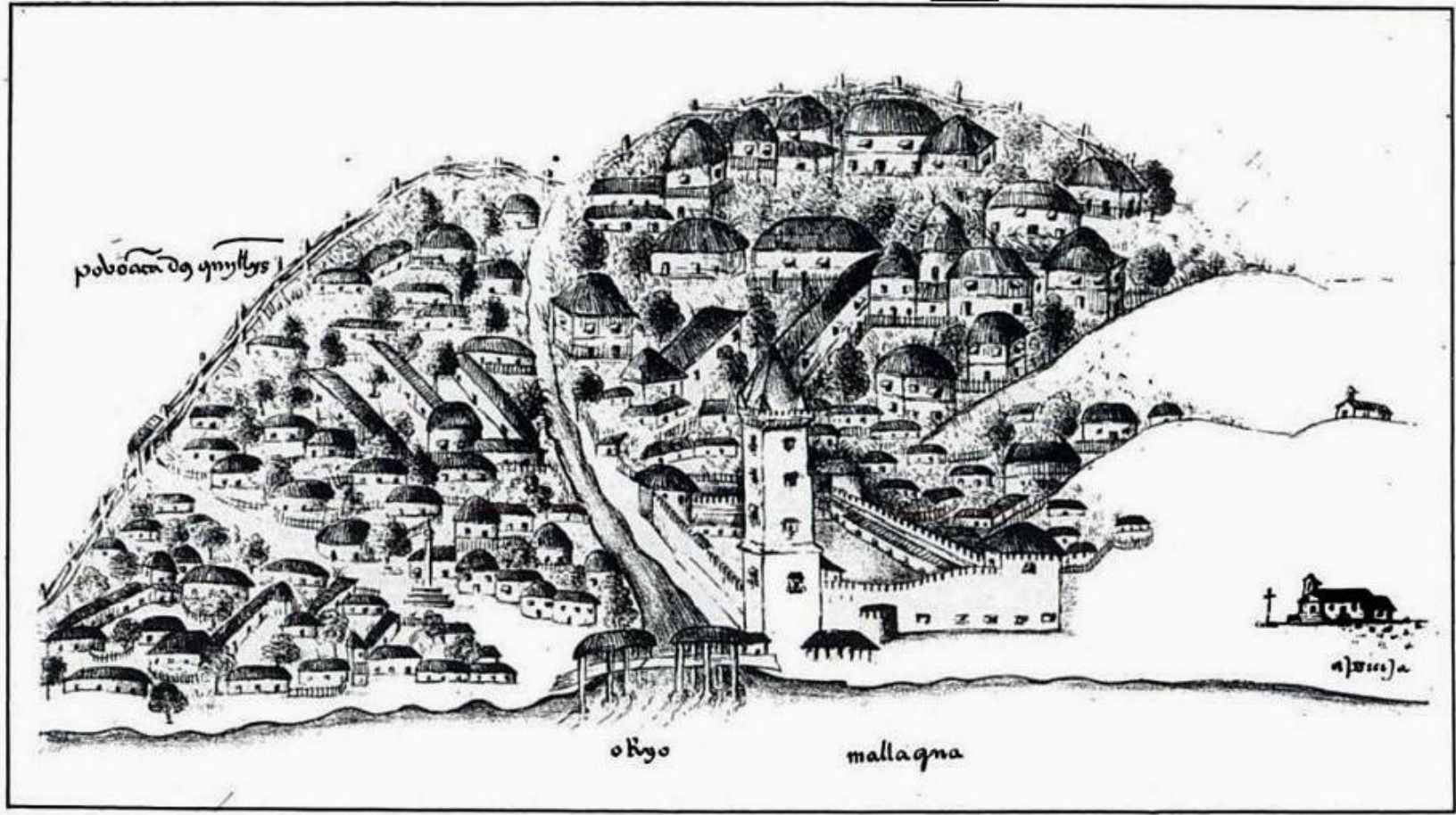

View of Malaca.

Fig. 7.The first paintings of Melaka City by Gaspar Correia in its atlas - The Da Lines of India around 1512 [18].

According to the painting, the first Fort A'Famosa built by the Portuguese was rectangular. Its position was below the foot of Bukit Melaka and along the estuary of the Melaka River which is also near the bridge stretching the mouth of the Melaka River. The city of A'Famosa in this painting has a relatively six-tower tower on the corner of the city near the bridge. Whereas, city fort or bastion on three other city corners are two-storey building. This painting also describes the City of Melaka at that time. The bridge across the Melaka River has a roof on either side. There was a road dividing the Upeh area (right side of the diagram) to the bridge. There was a fence around the settlement in Upehand densely populated areas in Yler(Hilir) behind Bukit Melaka. This painting also describes Bukit Melaka with less population than other areas and looks 'empty'. Buildings in the Upeh area appear to be altogether high while the Yler area has a wide range of buildings but more to two-storey buildings. Building materials of A'Famosa were clearly of stone or brick that is plastered on the outside. Other buildings consist of a wide range of wood-based materials, wooden and stone buildings, clay or stone buildings only.

Referring to the location of the city, it coincided with the statement of [19] in the preceding paragraph besides the writing of De Castanheda which states "They and the others get at one end of the bridge next to the (cliff) where the mosque and the sultan's palace are located, and Alfonso D 'Albuquerque, and the royal flag are at the other end (the bridge) the other...". The city's location according to the paintings and historical records refers to Fort A'Famosa, the first city built by the Portuguese in just four months after they conquered Melaka.

The rectangular shape of the A'Famosa was also mentioned in historical record as -"... Alfonso D'Albuquerque is now busy building a fortified city, where the mosque was once existed, and named 'Famosa' [18]. A'Famosa was built on the site of the Great Mosque of Melaka which features a rectangular shape as the custom of mosques designs in the Malay Archipelago realm at that time, then the A'Famosa was originally built in rectangular over the ruins (or damage) of the Great Mosque Malacca after the success of Portuguese colonization.

The existence of a six-storey review tower at A'Famosa is in line with the height of the mosque towers in the design of mosques in the Malay world. The bastions in the other three corners of this two-storey high-rise city illustrate the height of the original Mosque of Melaka, as in other mosques of other Malay kingdom at that time. In accordance with the following statement:

Tom Pires - "This King Mansur Syah (Mamsursa) built a beautiful mosque once located where the famous Melaka city is now and is the most beautiful in the region" [8].

Gaspar Correia - "There is a large mosque constructed of cubes (cubes) of stone, and also small buildings and tombstones are also constructed of stone" [8].

Hence, it should be that the beautiful and large mosque building is strongly built, higher than most other buildings around it, was built and decorated with all the beauty that is in Melaka as a symbol of the majesty of the mosque and Melaka. These statements and the first painting of A'Famosaillustrate the truth that the existence of the $A^{\prime}$ Famosa was built directly on the site or the ruins of the Great Mosque of Melaka.

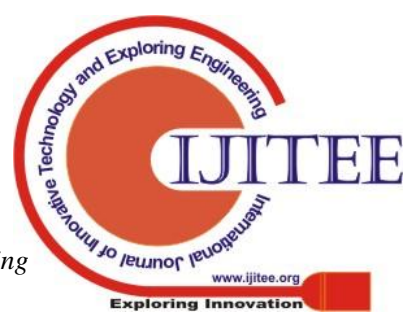


The bridge with roofed roof at both ends shows the importance of the function and design of the bridge as the main route nodes and places for active trading activity. This is because it is anxious for a bridge to have its own roof unless the bridge is important and plays many other roles besides the connectors between the two banks. In accordance with Ma Huan's statement in 1403, "On this river the sultan built a bridge, which had built on it twenty booths to sell various commodities" [20].

This shows that the bridge has become an active business area and route, so most probably the infrastructure has been upgraded well a century later. Establishing a roofed bridge infrastructure demonstrates the wisdom of the leader and part of its structure that continues to exist despite much damage during the war demonstrating the importance and integrity of the bridge so that's why it was also in the earliest painting of $A^{\prime}$ Famosa. Clear paths dividing the Upeh area towards the bridge and to Hilir/ lower Bukit Melaka area indicate that the route is the main road or highway inUpeharea which has probably existed since the reign of the Malay Sultanate of Melaka. This road is in line with the study of [21] which mentions:

"At the beach the authorities provide a safe warehouse space for storing goods, and transactions are done in small huts and shops that meet both roads to the beach and bridges that have been from the beginning of the Melaka empire, crossing the mouth of the Melaka River and connecting both parts of Melaka."

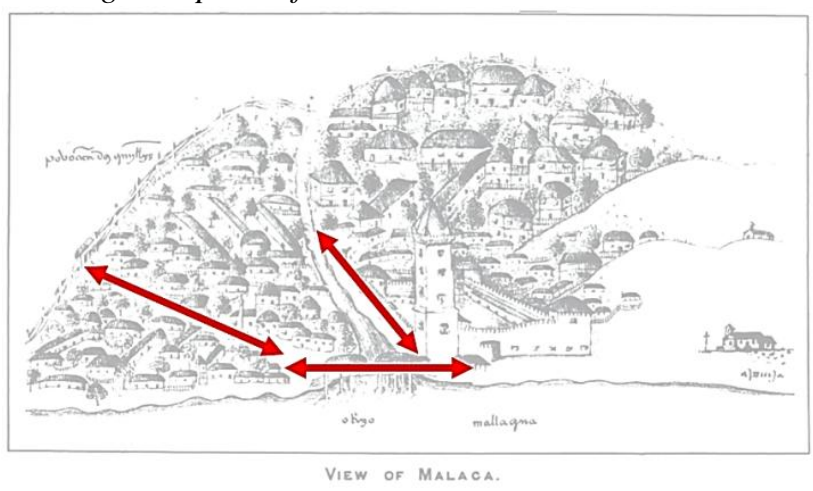

Fig. 8.The concept of the main road route of Melaka City extracted from the first painting of Melaka City A'Famosa [18].

The location of the road that splits Upeh and 'close to the beach and bridge' is likely to refer to the route which is clearly the main route and the advent of many business activities as Tom Pires emphasized, "as in Melaka they are selling in every street." [8]. The description of the fence in the painting that encloses the entire Upeh and Hilirsettlements is likely to indicate the borders of the Portuguese settlements or the early borders of the preceding city. However, referring to the paintings, the fence is the most extravagant border drawn on the Melaka City of early Portuguese colonization and no other details after the fence. This illustrates the emphasis on the focus of the paintings that would accurately reflect the city of A'Famosa and Melaka City. The lower population density of Bukit Melaka is possible because it was easier for Portuguese to inhabit horizontal areas than hilly, which will undoubtedly make it difficult for any hillside activity. In addition, the Bukit

Melaka area is empty without any construction because of the location of Melaka palace during the captivating war of Malacca was located in the hillside of Bukit Melaka. This also shows the difference in the selection of different central government locations - "They climbed the hill where the sultan had resided ... decided to revenge by burning the sultan's palace and royal prince's houses, and its top administrators" [8].

Average altitude of buildings in Upeh area shows that the Upeh was a dense population. The average altitude of the multi-storey buildings and most of them were two floors in the Hilir area indicate that the downstream area has a denser settlement population. This difference also indicates that Upeh is a settlement area and Hilir is a governmentsettlement area. This is seen synonym with the record in Malay History and information of Roy de Araujo which states that the Upeh area is a settlement area for most people and traders. The Hilir area is the settlement of the Sultan of Melaka's family, government officials and their families, and also for important traders who usually were their country's ambassadors. Because of this, the Hilirarea is seen to be denser and had variety of building height as a continuation of the Melaka Malay Sultanate even after the conquest by the Portuguese. This is because the Portuguese records does not mention either they burn or destroy all the houses and buildings found in Melaka City before rebuilding the Portuguese era of Melaka.

The A'Famosa Melaka was described as a building that uses stone material as a whole because it is constructed of stone from the ruins of mosques, tombstones of previous sultans and royals, and granite stones fromUpeh Island. This corresponds to the historical record contained in the Portuguese Documents of Malacca [8] mentions:

"A Famosa is partly built from the old tombstones of ancient kings planted beneath the surface of the earth, and from the rocks of the ruined mosques."

"The stones, granite stones, were taken from the tombstones of the Sultans, from the mosques and from other buildings."

"The stones, granite stones, were taken from the tombstones of the Sultans, from the mosques and from other buildings."

The overview of the variety of other building materials found in the early painting of $A^{\prime}$ Famosa shows that Melaka City before the Portuguese's conquest had their own style of architecture with construction system that use local building materials. The design of buildings also meets the needs and social status of the owner. This is in line with the information given by Roy de Araujo to Alfonso de Albuquerque stating that there were roughly 10000 houses in Melaka City and 500 of them were built entirely of stone while others were built with a mixture of stone and wood, wood and clay or only wood [20]. The early recorded statements and painting of the A'Famosa also proved two things that the buildings in Melaka City were partly the remains of the buildings during the Melaka Malay Sultanate era. The buildings built during the Malay Sultanate of 


\section{EXISTENCE OF MELAKA MALAY (FORT) CITY BASED ON FIRST PAINTING OF A'FAMOSA BY THE PORTUGUESE}

Melaka had reached distinctive development of entrepot city in the Malay world.

The first painting of A'Famosa City shows different designs than those in the next sketches of the Portuguese and Dutch era. The city's sketches and paintings highlighted the design of the hexagonal Melaka Fort City and the city line by the shape of the surrounding terrain - the city of Melaka was built in the form of hexagonal landforms between the Melaka River and the Leleh River which became its boundaries. For example,A'Famosa that was built by Portuguese as in the first painting of Melaka City differs from the last painting of $A^{\prime}$ Famosamade over a century later, before the Portuguese handed over the reign of Melaka City to the Dutch. TheA'Famosa has expanded encompassing almost all the Hilir land and the boundary of the drawing details has been expanded over Upeh and Hilir.

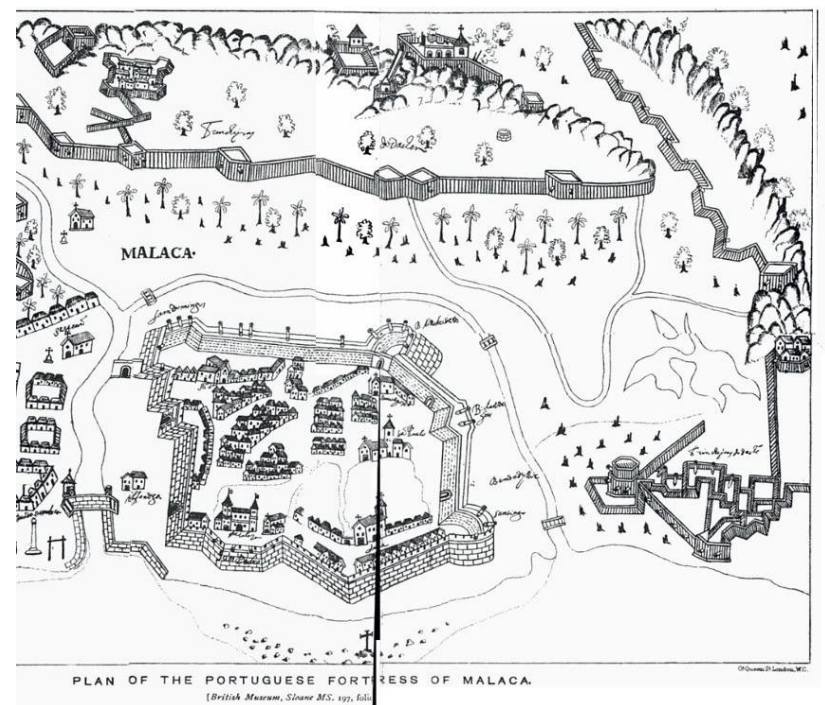

Fig. 9.Painting of $A^{\prime}$ Famosa during the Portuguese era before the Dutch rule [22].

\section{CONCLUSION}

In conclusion, this first painting shows the design of the Melaka City or A'Famosa City was in square or rectangular shape as it was built on the site of the Great Mosque of Melaka. The rectangular fort design was synonym with the design of other Malay forts or cities. Rectangular design was a fundamental design tradition in the Malay world from the fourth century until the later centuries after the collapse of the Melaka empire either in Johor, Brunei or other Malay clusters. This coincides with the urban philosophy and design of the Malay city and Islamic city that breed in the Malay Archipelago region at that time. However, the design of the rectangular fort or city was not synonym with the design of Portuguese forts or cities built around the world in their colonization expeditions which were built according to the design of the land where the forts were constructed.

The settlement of the Melaka city during Melaka Malay empire was a long constructive history from the day it was founded then went glorious till its collapse and conquered by Portuguese. Its geographical position and its shape have attracted external influences and had an important impact on urban development. Through the golden age throughout the Malay Archipelago until the fall of western power, Melaka is rich in historical heritage that is able to recount the moments of success and greatness of the Melaka Malay
Rulers. This paper is just a mere documentation of a historical heritage that should be preserved and disseminated for future generations. The splendor of urban heritage and Malay cities should be more prominent and more concern should also be given to the heritage conservation program of the city and the Melaka Malay city as what remains is an everlasting proof of our Malay cultural heritage.

\section{REFERENCES}

1 Roslan, Z., Ramli, Z., Shin, C., Er, A. C., \& Razman, M. R. (2017). Local community perception on the importance of cultural-natural heritage protection and conservation: Case study in Jugra, Kuala langat, Selangor, Malaysia. Journal of Food, Agriculture and Environment, 15(2), 107-110.

2 Rofiei, R., Mohd Tawil, N., Kosman, K. A., \& Che Ani, A. I. (2016). Understanding the people's needs of living in city: Scenario in Malaysia. Journal of Engineering Science and Technology, 11(5), 704-713.

3 Mat Sulaiman, M. K. A., Kosman, K. A., \& Ja`Afar, N. H. (2016). An assessment of students' understanding on anthropometry and ergonomic in shelter design execution. Journal of Engineering Science and Technology, 11(Special Issue onpendidikankejuruteraandanalambina), 40-52.

4 Kosman, K. A., Haron, H., Mohd Tazilan, A. S., \& Yusof, N. A. (2018). The typology of mortises in the traditional Malay house in Malaysia. International Journal of Civil Engineering and Technology, 9(3), 977985.

5 Abd Hadi, M. S. B., Ramli, Z., Nasir, M. N. M. M., \& Mori, J. (2018). The application of digital reconstruction in the documentation and interpretation of Candi Kampung Baru, Kota Kuala Muda, Kedah. International Journal of Engineering and Technology(UAE), 7(3), 5254.

6 Nasir AH. Kota-kota Melayu. Kuala Lumpur: Dewan Bahasa Pustaka; 1993.

7 Harun SN, Jalil RA. The History and Characteristics of Malay Early Towns in Peninsular Malaysia. 2014;02(03):403-9.

8 Pintado MJ. Portugese Documents on Malacca from 1509 to 1511. Arkib Negara Malaysia; 2012.

9 Vespucci. Paesi Novamente Ritrovati. Venice, 1521 1521.

10 Armando Cortesão e Avelino Teixeira da Mota Portvgaliae Monumenta Cartographiga Volume I, Imprensa Nacional Casa da Moeda, Lisboa 1960.

11 Twee on gelukkige scheeps-togten oost-indien van Jorge De Mello, in het Jaar 1507 en Jorge D'Aguiar, in het Jaar 1508 in het Jaar 1511. Beyde in het Portugys beschreven uyt de egte hand-schriften der reysigers op ordre des Konings van Portugaal door Joan de Barros Raads-Heer en History schrijver van die majesteyt.) - from book Empayar Melaka Tradisi Melayu Agung. Perbadanan Muzium Melaka (PERZIM); 2010.

12 Armando Cortesão e Avelino Teixeira da Mota Portvgaliae Monumenta Cartographiga Volume I-IV, Imprensa Nacional Casa da Moeda, Lisboa 1960-(1962).

13 Nasir AH. Kota-kota Melayu. Kuala Lumpur: Dewan Bahasa Pustaka; 1993. Page 195, 148, 182, \& 120.

14 Nasir AH. Kota-kota Melayu. Kuala Lumpur: Dewan Bahasa Pustaka; 1993. Page 89

15 V. MJ. Eredia's Description of Malacca, Meridiona India, and Cathay. JMBRAS. 1997.

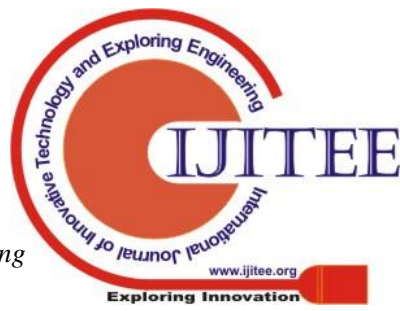


16 Macgregor IA, C. A. Gibson-Hill MA, Sieveking G de G. Papers on Johore Lama and the Portuguese in Malaya (1511-1641). J Malayan Branch R Asiat Soc. 1955;28(170): 199.

17 Hashim Y, Hussin N. Empayar Melaka Tradisi Melayu Agung. Perbadanan Muzium Melaka (PERZIM); 2010.

18 Correa G. Lendas da India. Lisboa: Academia Real das Sciencias de Lisboa, 1858-1866.

19 Graham W. Irwin. Melaka Fort. Paper presented at the Seminar Pengkisahan Melaka 2003-2006. 2006.

20 Liang L-C. Lembaran sejarah gemilang: hubungan Empayar Melaka-Dinasti Ming abad ke-15. Penerbit Universiti Kebangsaan Malaysia; 1996. 145 p.

21 Cho G, Ward MW. The Port of Malacca. Himpunan Kertas Kerja Seminar Pengkisahan Melaka 2003-2006; Perbadanan Muzium Melaka. 2006.

22 Livro do Estado da India Oriental, by Pedro Barreto de Resende. British Library; 1646. Sloane MS 197.

\section{AUTHORS PROFILE}

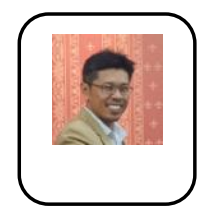

DrKamarulAfiziKosman is a Senior Lecturer in the Department of Architecture, Faculty of Engineering and Built Environment, UniversitiKebangsaan Malaysia. His areas of expertise are the history and theory of architecture. He also actively involved in cross-border research. The area of his research and publications are mostly related to the issues of an architectural identity, architectural language, Malay traditional architecture and architectural education. To date, he has authored 13 indexed journal articles, six books and seven chapters in book. His expertise is recognized from leading institution when appointed jointly by the Institute of the Malay World and Civilization (ATMA), UKM as a research fellow in 2007 and a year later he has been entrusted by the ATMA to lead a research group namely The Technology and Sustainability of Malay Civilization. In curriculum development, his significant contribution is when he serves as the Coordinator of Accreditation for the Bachelor of Science in architecture (UKM) programme in 2011. Finally, the programme has successfully been recognized in LAM Part I in 2012. Currently, he is a member of the assessors of Council Accreditation and Architectural Education Malaysia (CAAEM).

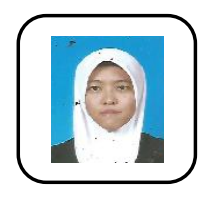

Noor AisyahMokhtar graduated in Bachelor (Hons.) Science of Architecture from UniversitiKebangsaan Malaysia in 2008. She pursued her study in Master of Architecture and graduated from University of Tasmania Australia in 2011. She is currently finishing her $\mathrm{PhD}$ thesis in Institute of Malay World Civilization, UniversitiKebangsaan Malaysia under the topic of 'Kewujudan Kota dan Bandar Melayu Melaka SebelumPenjajahanPortugis 1511'. 